\title{
1. Introduction: markets, competition, and higher education
}

In 1860 institutions of higher education in the US enrolled 20000 students, nearly all of them majoring in the traditional liberal arts (Burke 1982: 216). By 2000 , over 20 million students in the US were attending a college or university. While we do not know what they had as majors, there is information regarding the majors of those earning a bachelor's degree. Of 1237875 bachelor's degrees conferred in 2000, 36104 were awarded to students majoring in the liberal arts and humanities; if we add in the subjects that were part of the liberal arts education of 1860, the total of degrees awarded in the liberal arts rises to 185 960, a tremendous growth in numbers in 140 years (IPEDS, Table 248).

Growth is only part of the story, for higher education also experienced a significant transformation between 1860 and 2000. While the number of liberal arts majors greatly exceeds that of 1860 , it is only 15 percent of all degrees conferred. In 2000 many students earned degrees in areas that rarely existed in 1860, including 108168 in education (9 percent), 72555 in engineering (6 percent), 78458 in health professions (6 percent), and 257709 in business (21 percent) (IPEDS, Table 250).

These numbers tell us that the history of higher education in the US has been one of a revolution in both size and diversity of study. Economists might readily interpret the transformation of higher education indicated by these numbers as a case of colleges and universities responding to the marketplace. Through competition with other institutions to attract students, colleges and universities changed the curriculum and programs they offered. The idea that colleges and universities compete with each other would surely have resonance among economists (Goldin and Katz 2001: 1; Raines and Leathers 2003: 2; Geiger 2004). In opposition many members of academia worry over the commercialization of higher education and abhor the idea that markets and competition should influence academia (Bok 2003; Slaughter and Rhoades 2004; Washburn 2005).

This book will describe how the current concern regarding the commercialization of academia continues a long-standing dispute that was begun in

ancient Greece over the extent to which market economics could be applied to 
higher education. The two sides to that dispute were Plato and Aristotle on one side and the sophists on the other. As will be described in Chapter 2, the sophists were a group of immigrants who came to Athens and became professional teachers of higher education for a fee. Three sophists, Protagoras, Hippias and Isocrates, were the innovators of fee-based higher education. Plato and Aristotle did not like the fee-based approach to higher education. They believed that commercial activities were a negative influence on Greek society, including the use of them in higher education. The sophists defended their market behaviour of teaching for fees. Their defence of market techniques to develop a system of higher education in Athens encountered criticism from Plato and Aristotle and set off a dispute over the role of markets in higher education that continues today.

The reason the dispute has been so longstanding is that academia does not respond to competition in the same way that a business would. As non-profit organizations, colleges and universities have no bottom line of profits as a business does to guide its decisions as to whether they need a new program; they must make decisions based on consistency with the mission they have set for themselves. Determination of how well new programs match up with the mission of a college is arguable, however. Decisions and the discussions used to reach them regarding academia's responses to the competitive demands of the market for education are ideological not economic.

\section{SOPHISM AND VIRTUE}

Nevertheless economic arguments will always play a part in academic decisions. For much of its history, discussions within and outside of academia about the way it should respond to the marketplace have been couched in the terms of two competing ideologies, sophism and virtue. These two ideologies arose with the origins of academia in ancient Greece. Among early innovators of higher education, as will be described in Chapter 2, the sophists held that it should focus on practical subjects that could enable them to earn fees from teaching, while Plato and Aristotle believed that education should aim at virtue. We will see that in the historical course of discussion over academia's mission, virtue meant doing what was right in terms of what subjects students needed to study, with right being defined by the persons arguing for virtue as a mission. What I will call sophism referred to doing what sold by stressing practical subjects, with practical being defined in response to the marketplace of students.

To be sure sophism and virtue are not mutually exclusive. One can do what is right and be practical at the same time, and no proponent of a mission of sophism will be against virtue. Using the terminology of economics, virtue 
and sophism can be interpreted as complementary goods that go well with each other. The issue is one of stress of sophism or virtue, however, and of importance to an economist, it is also an issue of holding a favourable or unfavourable attitude toward the competitive market as a social tool. With due respect toward the virtuous persons who earn a living through market activities, such as the ancient sophists did, in this book I will use virtue as tantamount to a non-market approach to the mission of academia and sophism as synonymous with a market approach to the mission of academia.

Moreover we will see in this book that these two concepts of the mission of academia were linked to two methods of funding it, what I will call the endowment model with a non-market approach and the tuition-driven model with a market approach (see p. 16). As a historian of economic thought I will be paying attention to the relationships among markets, competition and academia associated with the tuition-driven model and with how persons concerned with the mission of academia perceived them. Consequently this book will be an intellectual history of how academics and economists understood the potential of markets and competition to influence higher education. From its earliest days academia has seen advocates of employing a competitive market approach to academia by stressing monetary gain as an incentive, and their story is a large part of what this book has to offer. Because those advocates used economic theory as it existed for them as part of their arguments, I will be looking at how economists analysed academia. Ultimately this book is a study of how the structure and the ideology of free-market competition have been used to define the terms under which discussions over the mission of academia have taken place in higher education, with a focus in the US during the period from 1630 to 1930 .

Before making that study, however, we need to understand the social benefits of the market approach as seen from the perspective of modern economics. Accordingly I will first describe the economic model of competition and explain how it applies to academia.

\section{MARKETS AND ACADEMIA}

The starting point in understanding the arguments of proponents of a market approach is the economic model of competition. The central assumption of modern economics is that scarcity is a fundamental human problem. To economists scarcity means that we do not have sufficient resources to produce everything human beings would like to have. Because resources are scarce in relationship to human wants, individuals, organizations and societies must make choices as to how to use the resources that are available to them.

Given this central assumption of scarcity, the prevailing view in economics 
is that the market system is a superior way for making choices about what to produce with our limited resources. If priorities must be set, what better way to set them than using economic incentives and letting each individual's or organization's willingness and ability to buy or sell determine those priorities? Let each person decide how best to earn a living through productive activities sold in a competitive market and then use the income from those activities to purchase goods and services from others in the market. In this way, the market system uses monetary incentives and competition to organize and order the social priorities of what to produce, how to produce it and who gets it.

As an underlying philosophy, economics holds that human beings respond to incentives. Individuals will vary as to what motivates them, and so an approach that brings about a wide array of types of incentives will contain something to motivate nearly every person. Markets are exceptional in creating this wide array of incentives.

Under the market system, if individuals want something and are willing to pay a high enough price, someone will produce it and sell it to them. To be sure producers can create wants in the sense that they offer consumers something they had never imagined - many new and innovative products do just that. Nevertheless it remains difficult to sell consumers something they do not want. Build it and they will come only works if the 'it' is something consumers want. In this sense the competitive market system weeds out products no one wants by punishing their producers with low prices and low or negative gains. The quest for success in making money carries an incentive to do the right thing as defined by competition in the marketplace.

In addition, competition in the marketplace has another important function. If a business produces a new product at a high price to make high profits, competitors will enter the market, bring prices down and restore profits to normal levels. Under competition, successful enterprises are the ones that attract customers and attract competitors. Competition will keep prices at the level needed to supply the market at an acceptable price.

Let me describe how a market approach would apply to academia by looking at a basic problem of scarcity in higher education. Given the time, typically four years, which students spend in getting an undergraduate education, they can only take a limited number of courses. Which courses should they take and how should they choose them? That is the basic dilemma of scarcity.

A market approach would say that students should choose whichever courses give them the most benefit. Since no one can read their mind and know what gives them the most benefit, they should be free to choose on their own. When all students make similar choices, a college would then have a clear incentive to offer the courses students want. Courses that do not attract students in sufficient numbers to cover their costs would not be offered very often if at all. Courses that had high enrolments and excess revenue would be 
offered with greater frequency. Institutions of higher learning that offered the mix of courses students wanted would succeed in the marketplace, and competition would settle the mission of academia. Colleges might even change their pricing system to charge by the course instead of by the semester, allowing them to charge higher prices for popular courses. This market approach is the essence of sophism.

In contrast, a non-market approach might say that higher learning should be operated to enable students to fulfil their basic human need for knowledge of what it means to be a good person. As a result higher education should be based on knowledge that students may not be expert enough to appreciate. They thus cannot be free to choose whatever courses they want to take, for they might miss filling their basic need for education. As experts on the knowledge of what it means to be a good person, academicians should define mission of education. This approach captures the spirit of virtue.

To see how well the economic model of competition applies to academia we must first look at its underlying assumptions. In its best form the model assumes pure competition with the following characteristics: there must be a large number of profit maximizing firms selling a standard product in a market with no barriers to entry; the firms and their customers must all have perfect knowledge about market conditions of price, production technology and product quality of all firms. Given these conditions, the only type of competition that is feasible is price competition. If all firms have the same product in terms of quality and consumers know that, the only way to gain customers is with a reduced price. This situation of pure price competition is what we usually mean by the process of turning products into generic commodities where the only quality that matters is price.

Economists agree that pure competition never exists in its ideal form. The purpose of the model is to look at a real situation to see which of the model's assumptions are violated and to examine what difference that makes in terms of the level of competition and the resulting price structure. In academia, for example, the suppliers are not profit-maximizing firms, and the quality of their products differs greatly in terms of prestige of institution, location, surrounding facilities and support services. There are barriers to entry by new institutions. It is not clear if students and their parents have sufficient information to make correct choices as to what college and what courses a student should attend. Because it does not face the conditions of pure competition, higher education has not turned into a generic commodity, and colleges and universities do not compete directly by price-cutting, although they may use scholarships to offer some students an incentive to attend in what is now called tuition discounting. Still there are enough colleges and universities in any particular market segment and geographic area to give prospective students a range of choices and produce a reasonable amount of 
competition. The question then becomes what type of competition characterizes academia.

In economic terms the model that best applies to academia is monopolistic competition (Paulsen 2001). Under this model business firms try to attain a competitive edge by competing not based on price but on quality differences or the perceptions of quality differences. The advantages are short-lived, however, because other firms can copy the quality differences and the initiator loses its competitive edge. In academia this model translates into the type of competition whereby individual institutions continually add programs or facilities in what is referred to as an 'academic arms race,' only to see other institutions follow suit.

In considering the type of competition academia faces we must bear in mind that it must concern itself with money even when its mission is virtue, because at a minimum it must gain the resources it needs to function. It has options as to how to get those resources, and to explore those options and show how they determine the nature of competition in academia I will use two models of how a college might handle its funding, the endowment model and the tuition-driven model. Although the models are general, the particulars reflect the system of higher education of the US, the subject of much of this book.

\section{THE ENDOWMENT MODEL}

The endowed college secures its funding from patronage, that is, wealthy benefactors, foundations or the government. For the purposes of this book, I will make no distinction between a private endowment that generates income and a public subsidy. In economic terms, annual funds from a government are equivalent to the income from an invested endowment and just as variable. Regardless of their source or effective functioning the funds the endowed college collects from its patrons would have to be ample enough to pay for buildings, equipment, libraries, books, operating expenses, faculty salaries and so on. If patrons were sufficiently generous, there would be no need to charge students tuition for attendance. The college would be able to accept the best students regardless of their economic status; it could also set the number of students at a low level, enhancing student-faculty interaction. Faculty would be free to teach those subjects they deemed most worthy. They would be under no competitive pressure to respond to the market as represented by students' wants.

The problem for the endowed college is that instead of responding to the market, it might have to respond to the desires of its patron. While the patrons might not give direct orders, they could try to influence how colleges use their money, including conditions on what they teach, who teaches it, and what 
students are to be taught. Yale University, for example, experienced difficulty in the mid-1990s with a \$20 million gift tied to the study of 'Western civilization.' Yale eventually returned the gift and placed itself in jeopardy of losing even larger gifts from the donor's family. To be autonomous the endowed college would need the support of a philosopher-patron wise enough to fund the best education; we will see in Chapter 2 that Plato and Aristotle followed this approach. The second best alternative would be the condition of having a large, diversified body of patrons, with no single patron able to exercise influence. Then the college could focus on its own definition of virtue.

From an economist's perspective the endowment model poses problems related to the incentives it provides the members of academia. First, if the endowed college wanted to expand its size or the diversity of its programs, it would have to find more funds from existing patrons or find more patrons. It must do the same to gain funds to increase faculty salaries. Finding more funds from patrons is not easy, however, and the persons who were adept at it might be in a position to influence the way the endowed college is run. Administrative leaders may be chosen for their ability to work with wealthy individuals, corporate donors or with government officials instead of being selected for their appreciation of the value of higher education. To influence potential patrons they may tilt the way they use existing funds to present a better image of the college or university to these patrons in an effort to raise even greater sums. They may also promote academic programs they believe patrons will support. The funds expended in pursuit of patronage might be better used in the process of teaching and learning, but they are instead spent in the process of competing for endowment funds. The endowment college does not eliminate competition; it must compete with other endowed colleges for the support of patrons.

Second, the idea that an endowed college enables professors to teach what they want and how they want gives them a great deal of freedom. The question is how they will use that freedom. There is a possibility that professors will take advantage of their freedom to do a minimal amount of work, since their income does not depend on how hard they work or how much they accomplish. I make no judgment on the validity of this potential problem, but indicate here that it forms a part of the discourse this book examines. State legislators in the US are coming to hold this potential problem as a real one and are trying to get colleges and universities to assess the outcomes they produce as a way of demonstrating what they have accomplished to justify their funding at the expense of taxpayers (Berdahl and McConnell 1999: 82). In addition, to ensure that faculty do not admit a small number of students to make their life easier, state governments usually impose enrolment targets on institutions of public higher education or base funding on the number of students. They also mandate that students be required to take specific courses. Patrons may seek accountability from the institutions they endow. $\mathrm{Dona}$. Stabile - 9781847207166 
A third problem raised by the endowment model is its impact on students. If tuition is free or low, there will be an excess demand in terms of the space available at the endowed college. In this case prices will be below costs and will not be effective in sending signals as to how best to allocate resources. Prices will also not function well as a rationing device that acts to price some students out of the market. A selection process must be used to allot those spaces. Because they pay little or no tuition, students may not have an incentive to concern themselves with the quality of the education they are receiving. Students must experience the education at a particular school to assess its value but may not be in a strong position to judge that education and may not be concerned to find out. If all colleges are endowed with free or low tuition, they may compete based on quality to attract better students, but they have no clear incentive to do so.

The point of all these problems with the endowment college is that its tilting toward a non-market approach requires a virtuous attitude among its stakeholders - patrons, administrators, faculty and students. Whether they have that attitude then becomes the issue. Values matter when virtue is used as a guide.

\section{THE TUITION-DRIVEN MODEL}

To look at the tuition-driven model let us begin with a simple educational scheme. A group of professors joins forces to create a college. The teaching process is the professor at one end of a log and students at the other end. (We will see in Chapter 2 that the sophists started out this way.) Suppose the college has 100 professors and 1000 students paying $\$ 10000$ a year, then each professor could earn $\$ 100000$ per year and enjoy the excellent relations inherent to a low student/faculty ratio of ten to one.

The economics underlying decisions at this college are quite simple. Do professors want an increase in pay? Then they must increase tuition or teach more students (increase the number of students or decrease the number of professors). Does the college want to build classrooms and a library? They must apply the same approach of higher tuition, more students or fewer faculty as a source of funds, along with the possibility that professors take a cut in pay. Does the college need non-teaching administrators or teacher-administrators with reduced teaching schedules? The same approach applies. Does it want to offer scholarships? Then it must use higher tuition from one group of students to subsidize another group of students. The only way to pay for additional resources is to shift the costs of securing them to students through higher tuition or to professors by more work or less pay. The tuition-driven model means that colleges have to pay attention to the market approach, that is, it must adopt sophism. 
If the college existed in isolation, it could expand its programs and facilities by pursuing the approaches most palatable to professors, such as increased tuition, reduced pay or increased teaching load. Faculty members can offer a curriculum that they think is best, as long as enough students pay to take it so all the bills can be paid. However, colleges do not exist in isolation and tuitiondriven colleges compete with each other to gain the favour of students. To attract them the tuition-driven college may offer students better quality programs or amenities such as social organizations and sports teams. These methods involve increased costs and can counter the hoped for gain from more students or higher tuition. Moreover competition might lead to lower tuition for students (or at least tuition discounting), which is one reason academia does not like competition. When all tuition-driven colleges try to expand in this competitive process, moreover, they may eventually have to attract students who will not be interested in the curriculum they offer. This then results in pressure to make compromises by offering those students at least some of the courses and programs they want.

But tuition-driven colleges need not offer every course students want. After all, even though the tuition-driven college must pay attention to the market, it does not operate to produce a profit. While it must try to see that the new programs it offers do not cost more than the gain they will get from more students and higher tuition, it does not have to worry about whether its academic programs produce gains. Popular programs that attract students can coexist along with less popular programs, as long as there are enough students to pay all the bills. Faculty members may earn differential pay based on those differences in program popularity, but only if that is what is needed to attract professors. The tuition-driven college must respect the market, but not cave in to it. It may be business-like in some aspects of its operations, but it is not a business in pursuit of profit and the accumulation of wealth.

Because the tuition-driven college does not aim at a profit, professors may face the same motivation problem that the endowment model has. Unless individual faculty pay is directly tied to student tuition, professors will have no incentive to worry about whether students take their courses, that is, their pay will not be dependent on their individual enrolments. If the tuition-driven college endeavours to expand the number of students it takes in to bring in more revenue, faculty will have no direct incentive to cooperate in this effort. Only if faculty are rewarded for doing what is needed to attract students will they willingly do so. Sophism requires reliance on economic incentives.

The big problem facing the tuition-driven college is finding enough students with the ability to pay for the courses it offers. Since students may not be knowledgeable consumers, the tuition-driven college may try to attract them with non-price and non-education qualities. These cost money, however, and as tuition-driven colleges use them to attract students they create 'Wasteful' 
competition whereby all colleges spend money on non-essential (for education purposes) items, such as programs of athletic competition. This approach can cause tuition to rise to pay for those items, and it becomes a possibility that tuition-driven colleges may be placed in a bind. If they try to compete by reducing prices (offering scholarships), they may be spending money on amenities while taking in less money from tuition. Competition can lead to ruin for tuition-driven colleges at worst or continuing financial difficulty at the least.

In addition this type of competition can have detrimental effects on students. Some of them may become priced out of the market by rising tuition; and students most in need of education may be least able to afford it. Students who can afford it may come to act like consumers who feel they can take what they like of what they buy and ignore what they dislike. They may also see faculty as service workers there to see to their wants. Finally, they might feel that if they are paying high tuition to attend college, they will need to earn high incomes to recoup their spending (or pay off their student loans). High tuition may lead students to view education as an investment, for which they must attain an adequate return by majoring in disciplines likely to yield high future earnings. They may feel compelled to sacrifice virtue for sophism.

As a tentative conclusion of this discussion of the tuition-driven model, we may say that the tuition-driven model will have a tendency to tilt its mission toward sophism in order to attract students. From the previous discussion of the endowment model we can see that in contrast it has greater latitude for a mission of virtue, depending on the wishes of patron. Of greater salience for the theme of this book few institutions of higher learning apply either model in its pure form. Rather they function under aspects of both models, resulting in a combined model, to which we now turn.

\section{THE COMBINED MODEL}

For much of its history, as well as in its current state, academia has exhibited features of both models. Many colleges and universities have endowments that they use to support their programs; public colleges and universities and some private colleges receive government funds that enable them to function without being completely tuition-driven. This enables them to maintain a balance between virtue and sophism, between offering an education aimed at creating the good person and one aimed at making that person productive to society.

While it can meliorate the different problems of the endowment model and the tuition-driven model, the combined model has its own problems in that it has the benefits and difficulties of both models. To the extent that institutions of academia have an endowment, they are protected from the competitive 
pressures of the marketplace, but must put up with the desires of patrons. They are able to offer their education to students at a tuition that is below cost, which should ensure them of a steady stream of enrolments. At the same time they may increase their costs to attract better students by offering a wider range of courses than their market can consume at cost-effective levels. Their strategy may depend on shifting those increased costs to someone else such as the government or wealthy donors. When patronage declines they may need to raise tuition and then face all the problems of the tuition-driven model.

The combined model shows that academic institutions are not businesses seeking a profit. The endowment model focuses on doing the right thing, as defined by the endower. The tuition-driven model has to attract students who can pay their fees, but only enough of them to pay the bills. Nevertheless colleges and universities, like businesses, are in competition with each other and must respond to the marketplace. They must compete for donations and for tuition paying students. They do not, however, need to compete under the terms of a business system where they need to worry about earning a profit and accumulating wealth to expand operations.

This method carries over into the areas of academia where a more direct market approach exists. Colleges and universities operate a variety of 'auxiliary enterprises' that function as economic enterprises such as bookstores, dining facilities, hospitals and residence halls, and they may generate surplus revenue. Major research universities now engage in a variety of research programs with an aim of making money for themselves or for the professors who undertake the research, selling intellectual property to private sector corporations. However they do not aim at making a profit; because they rarely take the surpluses they earn from these activities and use them to expand their activities to gain further surpluses. More likely those surpluses are used to subsidize the academic functions of the college or university, that is, they are best considered as part of the overall resource structure of the institution. Regardless of how they are considered, for the remainder of this book, I will be concerned primarily with the application of competition to the strictly academic part of higher education, to its mission of teaching and learning.

There is one other issue that needs to be addressed in any discussion of the economics of academia, the demand for higher education. Students have three interests in college studies. A small percentage wants to learn something. Not all of those seeking knowledge are seeking virtue, as they may study practical areas such as engineering, pharmacy, medicine, or even business. A large percentage of students are anxious to get documentation necessary for a job. The remaining group is looking for the entertainment afforded by campus life, football, basketball, social contacts, and so on. This book will not address the issue of why students choose to attend college, except to the extent that the intellectuals surveyed in it imputed motivation to students. 


\section{OVERVIEW}

Overall this book is about intellectual discourse over the mission of higher education and the effect markets and competition might have on it. Following this introductory chapter, Chapter 2 will present a survey of higher education among the Greeks; it will start with the dispute in Athens between the sophists and Socrates, Plato and Aristotle over the nature of education and the role fees should play in it. Chapter 3 will look at the medieval period to eighteenth-century England and will highlight Adam Smith's sophism as evinced in his proposing monetary incentives in academia. Subsequent chapters will shift the focus to the US. Chapter 4 begins with a discussion of academia at a time when colleges remained small and under the endowment model and will show cases where sophism began appearing; Chapter 4 will also include the utilitarian ideas of Jeremy Bentham on how to improve academia as a portent of the growth of large universities from the endowment model. Chapter 5 will consider how John Stuart Mill argued for public higher education as a competitive force for private universities and will describe the growth of universities in the US in the late nineteenth-century through expansion of the curriculum. Chapter 6 will start with discussion of how Alfred Marshall's marginalist economics offered new lessons for academia and will investigate the extent to which academia followed the pattern set by business in the US in the early twentieth-century, using the ideas of Thorstein Veblen as a benchmark of what it meant for academia to act in a business-like fashion. Chapter 7 will offer a brief survey of the rise of collegiate schools of business as a case study of an academic response to the market. In Chapter 8, I will offer some conclusions and speculate on the future of academia as it may be influenced by the beginnings of for-profit universities dominated by sophism.

Regarding the economists included in this book, one of the problems in the history of economic thought is in determining just how influential any particular economist was. In the case of Adam Smith, for example, we will see that his ideas regarding academia were repeated in the US. Evidence of similar influence in the US by other economists in this book has not been as easy to find, but all of the economists reviewed in this book have been prominent figures in the history of economic thought. The other thinkers whose ideas form a part of this book have been picked because their ideas relating to academia have been preserved and made readily accessible to scholars. Many of them were socially influential in one way or another, but we will see that their ideas regarding the discourse of this book were not always as influential as they were. 


\section{CONCLUSION}

The purpose of this book is to examine the historical expression of ideas over the role of competition in academia. In writing it my purpose is not to determine the right or wrong side of the argument. Rather I am hoping to shed light on current discussion over academia and the marketplace by looking for insights from an earlier time that are still relevant today. Specifically I believe that much of the debate over academia and the marketplace confuses getting resources to facilitate the production of education with the profit-making attitude of business.

Because academia's response to changing economic conditions has not been nearly as direct as a business's response would be, the historical record of academia and the marketplace has been neglected. Consumer preferences change, however, and in the case of academia, consumer preferences have been moulded by the economic system of capitalism that has arisen in the US since 1860. The expansion and transformation in academia in this period has been an accommodation to the needs of a capitalist system that did not exist when institutions of higher education were first formed. The question then became whether academia would enter into the competitive arena that is intrinsic to capitalism. 